\title{
まちづくりに関わる都市計画マスタープランの計画文書の計画技術の研究 PLANNING METHOD OF THE PLANNING DOCUMENTS OF MASTER PLAN FOR URBAN HUSBANDURY
}

\author{
饗庭 伸*, 佐 藤 滋** \\ Shin AIBA and Shigeru SATOH
}

\begin{abstract}
The purpose of this paper is to clarify the preparation method of the master plan as common information infrastructure of urban husbanduary developed in multisubject, by the report of the example of city master plan of Tsuruoka City, Yamagata Prefecture.

In the paper, we showed the method for distinguishing the planning documents which are issued in the process of urban husbanduary with the two distinction, the desicion type and process type. Then we clarified the method for integrating the planning documents in the master plan with the distinction
\end{abstract}

Keywords:Master Plan, Urban Husbanduary, Planning Documents, , Field of Consultation マスタープラン, まちづくり，計画文書，協議の場

\section{1 研究の背景と目的}

都市計画の課題は変化し、市民サイドの多くの主体をその担い手 に想定した「まちづくり」へと広がってきた。「市町村の都市計画 に関する基本的な方針」（都市計画法第18条の 2 による。以下都市 M P ) は、法定都市計画に関する計画内容を取り扱うMPであるが、 法定都市計画と関係の薄い事項も記述した都市MPが実態として多 く見られる。すなわち市町村のレベルで都市計画の領域を拡大する 試みがなされている(1)。また、例えば市民版マスタープラン(2)とい う取り組みや、都市M P 策定に関わった組織が策定後も活動を継続 させるという事例(3)も多く見られ、市民サイドの主体が都市ＭPを 中心とした市町村のまちづくりの担い手として役割を担いだしてい る。つまり、「課題と主体の多様化」が都市計画に起きている変化 であり、このような現在、都市MPの役割は、行政が主導的に行う 都市計画の方針を示すだけでなく、多主体で中長期的に個別的に展 開されるまちづくりの中で発行される、各種の計画に関する文書 （以下計画文書）を集積した情報基盤として捉えるべきである、と いうのが筆者の仮説である。本研究ではこのような都市M P の作成 の方法を、山形県鶴岡市における都市MP策定の奏例を報告しつつ、
明らかにすることを目的とする。

次に既往研究をレビューし、本研究の位置づけを述べておく。92 年辣以後の市民参加をともなう都市 $\mathrm{MP}$ 策定の研究や実践の報告 は、(1)策定の手続きとしての市民参加に関する研究・報告(4)(2)「市 民版マスタープラン」に関する研究・報告(2)(3)ワクショップ手法 を活用した参加の場の充実に関する研究・報告(5)(4)策定過程から生 まれる市民組織に関する研究・報告(3)の 4 点にまとめられる。(1) (3)の研究・報告は、92年以降に策定された都市M P の策定の一時点 に着目した研究であり、中長期的に都市M P の運営と個別のまちづ くりの関係を観察するものではない(22)が、策定プロセスにおいて発 行される計画文書について多くの報告がされている。(4)は都市MP 策定以後に策定に携わった市民が自主的に活動する実例を示し、そ のような市民活動を都市MP の策定や見直しにあたって意識する必 要性を指摘したものである。(1)(2)(3)において報告されている「市民 からの提案集」「回答集」などの文書は策定の一時点における応答 関係を担保するものとしてだけでなく、情報基盤を形成するものと して重要であり、(2)(4)で報告されている都市M P と関係を持って活 動する主体は、情報基盤を共有する、中長期的なまちづくりの担い
$*$ 東京都立大学工学研究科建築学尃攻 助手 $\cdot$ 工修

** 早稲田大学理工学部建築学科 教授. 工博
Research Assoc. Department of Architecture and Building Science, Graduate School of Engineering, Tokyo Metropolitan University, M. Eng.

Prof., Department of Arch., Faculty of Science and Engineering, Waseda University, Dr. Eng. 
手として重要である。本研究は、(2)(4)のような多主体が展開するま ちづくりにおいて、(1)〜(3)の過程で生み出される情報を中心とした 様々な計画情報を、都市M Pに蓄積していく方法を明らかにするも のである。

なお、本研究で言う「まちづくり」は「行政サイドと市民サイド の主体が何らかの課題に対して、協議の場を設けて方針を決定し、 その解決にあたる行為」のことである部。市民サイドの主体は必ず しも一つではなく、また、具体的な課題から総合的な課題まで多く を対象にし得るが、どれだけの課題を対象にするか、つまり個別的 に展開されるまちづくりのどこまでを都市MPで取り扱うかは、各 主体が地域特性に応じて決めることであり、状況に応じて変化する。 すなわち、まちづくりに関わる都市 M P は、一群のまちづくりの課 題の協議の場に参加する多くの主体が、やり取りした計画文書を編 集して作り上げるマスタープランである。

\section{2 既往の方法の整理と本研究の射程}

都市MPは92年に創設されたが、それ以前の地方自治法による市 町村の総合計画や、任意に作成されていたMPにおいて、「まちづ くり」との関係づくりを図った取り組みが行われている。次に、既 往の取り組みですでに確立されている方法を整理しつつ、本研究で 明らかにする方法上の課題を示す。

まず、「気運の熟した課題や地区から協議の場を設け、段階的に MPを作成する」という全体の進め方に関する方法がある。これは、 70 年代の町田市の総合計画の取り組み社に始まり、以後数は少ない が、区を70に分け、段階的に計画を作成している東京都足立区の地 区環境整備計画( や地区を絞って、主体を巻き込みながら進める必要があるために採 られている方法である。本研究では前述の通り、都市MPに個別的 に発行される計画文書を含むこととしており、この方法を前提とす る。

次に、個別のまちづくりで多く発行される計画文書を区別し、都 市MPに体系化する方法がある。個別のまちづくりでは、事前の協 議から実践の段階に移るにつれ、多くの主体が関わり、基本的な方 針の決定、詳細の決定など、様々なタイプの決定が為される。計画 文書はこれらの決定を表現したものであり、(1)まちづくりのどの段 階で発行されたものか、(2)どの主体が関わって発行されたものか、 (3)どのような決定が表現されているかの 3 点から区別される。この ような区別に基づいて計画文書を都市 M Pにおさめる方法が考えら れるが、既往の取り組みは、このような方法が明確ではない。した がって、多くの既往の取り組みにおいて、地区カルテ、市民からの 提案集、住民参加の記録集、回答集など様々な計画文書が発行され ているが、必ずしも体系的に発行されていない。本研究では、これ ら計画文書を上記の(1)(2)(3)の視点から区別し、体系的に都市MPに おさめていく方法を明らかにする。
以下の論文では、まず計画文書を区別する方法を示し（3）、次 に鶴岡市において発行された計画文書を区別し（4)、最後に区別 に基づいた計画文書の佻系化の方法を提示する（5）。

\section{3 計画文書の区別}

既述の通り、個別のまちづくりには、事前の協議から実践の段階 に至るまで様々な段階が含まれるが、ここでは、都市MPにおさめ る計画文書を、実践を伴わない協議の段階で発行された計画文書と するモデルを考える。ざなお、学習や課題発見を経て、基本的な 方針の決定に至るまでの段階である。その場合の、計画文書がやり 取りされる協議のプロセスをモデル化すると、図 1 のようになる。

モデルは、行政サイドの主体、市民サイドの主体、協議の場で構 成され、市民サイドの主体は、協議の場に直接参加する主体（図中 主体 $\mathrm{A}$ )、協議の場には直接参加しないものの、課題と関連が深い 主体（同主体 $\mathrm{B}$ )、不特定多数の市民に大別される。協議の場は具 体的には個別の会合（以下WS）で構成されており、WSは複数回開 催される場合もある。

計画文書はこの協議のプロセスの様々な「段階」において、「主 体」や「協議の場」間でやり取りされるものであり、「段階」と 「主体や協議の場の発信元一受信先の関倸」の 2 点から、図 1 ・表 1 に示すとおりa〜oの15タイプに区別しうる。まず、「段階」で区 別すると、協議の場に対して準備される事前準備的な文書（以下事

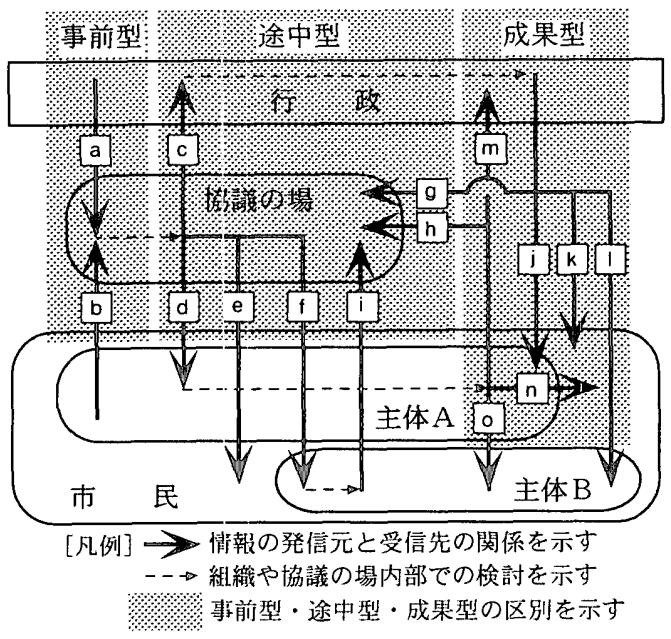

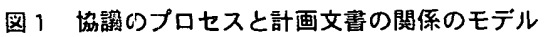

\begin{tabular}{|c|c|c|c|c|c|c|c|c|c|c|c|c|c|c|c|}
\hline$\underbrace{\text { 受霹先 }}_{\text {発信元 }}$ & \multicolumn{3}{|c|}{ 行政 } & \multicolumn{3}{|c|}{ 協議の場 } & \multicolumn{3}{|c|}{ 主体A } & \multicolumn{3}{|c|}{ 主体 B } & \multicolumn{3}{|c|}{ 市民 } \\
\hline \multirow[b]{2}{*}{ 行政 } & & & & 舟 & 氹 & 成 & 事 & 途 & 成 & 事 & 途 & 成 & 和 & 途 & 成 \\
\hline & & & & a & $\mathrm{g}$ & - & - & - & j & - & $\overline{-}$ & 1 & $\overline{-}$ & - & $\mathrm{k}$ \\
\hline \multirow{2}{*}{ 協䣡の場 } & 事 & 途 & 成. & & & & 事 & 途 & 成 & 事 & 途 & 成 & 事 & 途 & 成 \\
\hline & - & c & - & & & & - & $\mathrm{d}$ & - & - & $\mathrm{f}$ & - & - & $\mathrm{e}$ & - \\
\hline \multirow{2}{*}{ 主体A } & 事 & 途 & 成 & 事 & 途 & 成 & & & & 事 & 途 & 成 & 事 & 途 & 成 \\
\hline & - & - & $\mathrm{m}$ & b & $\mathrm{h}$ & - & & & & - & - & 0 & - & - & $\mathrm{n}$ \\
\hline \multirow{2}{*}{ 主体 B } & 事 & 途 & 成. & 率 & 途 & 成 & 整 & 途 & 成 & & & & 重 & 途 & 成 \\
\hline & - & - & 2 & - & i & - & - & - & 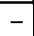 & & & & - & - & - \\
\hline
\end{tabular}

[凡例] 事: 我前型 途: 途中型 成: 成柴型を示す

婊 1 計画文蓄の区別 
前型)、協議の最中に協議の場と各主体の間でやり取りされる途中 経過的な文書 (以下途中型)、最終的にまとめとして出される最終 成果的な文書（以下成果型）の3つに大別できる。この3つを「主 体」や「協議の場」間の関係で更に区別すると、a〜oの15タイプ となる。まず設置された協議の場に、参加する主体がそれでれ計画 文書（文書a・b）を持ち寄る。協議が行われ、その結果が文書c〜f として各主体や不特定多数の市民に対して発信される。発信された 文書は、各主体の組織内部で検討され、結果が組織の外部に向けて 発信される。継続的な協議が必要な場合は、文書g〜iが協議の場に 発せられ、引き続きWSが開催される。協議が終了する場合は、行 政と主体Aから外部に対して文書j〜oが発せら扎る。事前型の文書 は文書a、b、途中型の文書は文書c〜i、成果型の文書は文書j〜oで ある。また、「協議の場」の構成員が協議の過程で組織化され主体 となる場合、あるいは「協議の場」に参加する市民サイドの主体が 課題に対して意思を持てない場合には、「協議の場」から出される 文書c〜fが成果型の文書となる。

a〜oの全ての計画文書は、それを発信する各主体の組織内部や協 議の場において、何らかの「決定」が為されて発行されたものであ

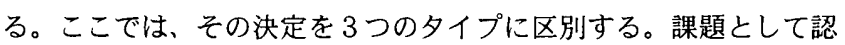
識するという決定、具体的な対応を提案するという決定、自らの事 業として取り組むという決定である。それぞれの決定に対して発行 される計画文書を、「白書型計画文書（以下「白書」)」「提案型計画 文書（以下「提案」）」「方針型計画文書（以下「方針」）」と呼ぶ。 また、提起された課題が幾つかの課題に具体化され、それぞれに対 して異なる対応が決定される場合があるので、一つの課題に対して 複数のタイプの計画文書が発行され得る。

以上まとめると、協議のプロセスの中から、計画文書は事前型、 途中型、成果型として発行され、それらは主体間の関係で更に $\mathrm{a}$ ～ ○の15タイプ (以下プロセスタイプ) に区別される。これらはさら に決定のタイプにあわせて「白書」「提案」「方針」の3タイプ（以 下決定タイプ）に区別される。

\section{4 鶴岡のまちづくりで発行された計画文書の区別}

\section{1 ) 鶴岡のまちづくりの概要}

次に、プロセスタイプ、決定タイブをもとに、鶴岡市の一連のま ちづくりで生み出された計画文書を区別する。鶴岡市は山形県庄内 平野に位置する人口約10万人の都市で、隣接する酒田市と並ぶ、生 内地方の中心都市である。城下町として市街地の周囲を農地や山林 で囲まれた完結した都市形態を持ち、中心部が城下町を基盤とする 歴史的な市街地、周辺部が区画整理などで形成された新市街地で構 成されている。全体として良好な市街地が形成されており、突出し た問題がないため課題は少ない。そのため、市民サイドの主体とし

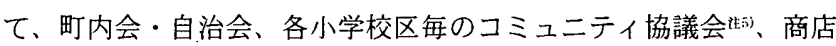
街組合があるが、モール化などの事業を実施した商店街組合を除き、
表 2 課題の一覧

\begin{tabular}{|c|c|}
\hline 課題名 & 協議の場 \\
\hline A.鶴岡市全体のまちづくり & 協議の場(1)，(2) \\
\hline 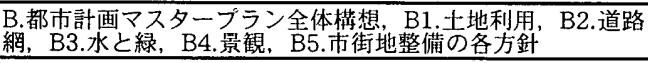 & 協議の場(2) \\
\hline C.第三学区全体のまちづくり & 協議の場( \\
\hline D.鶴岡公園と街路整備事業 & 協議の場(1) \\
\hline E.大道堰の課題, 活用 & 協議の場(1)，(5) \\
\hline F.中心市街地の活性化 & 協議の場(4) \\
\hline G.山王通り商店街の活性化のための事業 & 協議の場(3)，(4) \\
\hline $\begin{array}{l}\text { H.ジビックソーン地区の課題, 将来イメージ, 街路の景観 } \\
\text { デザイン }\end{array}$ & 協議の場(6) \\
\hline
\end{tabular}

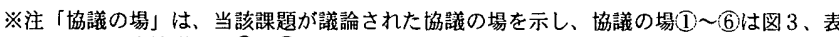
3、図 4で示す協議の場(1)〜6と対応している。

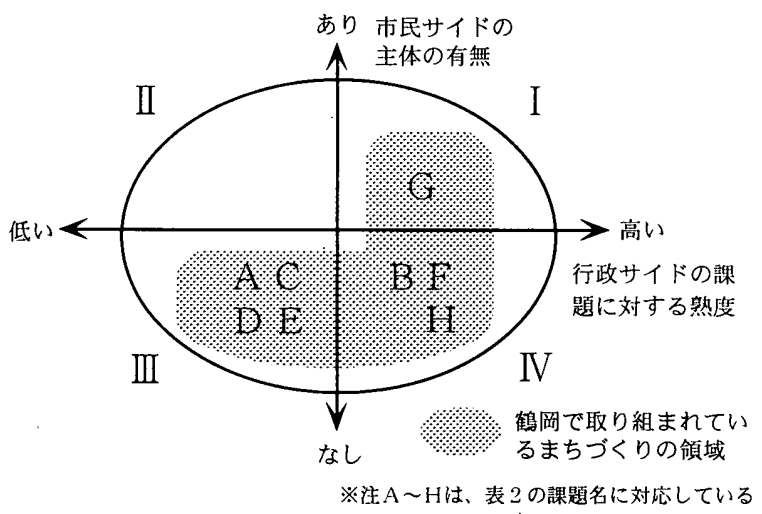

図 2 課題の類型

近年何らかのまちづくりに関する課題を提起して活動を行ったとい う経緯は無い。

このような中、鶴岡では80年代後半から景観形成基本計画（90 年）等に位置づけられた都市づくりの事業が中心市街地を中心に計

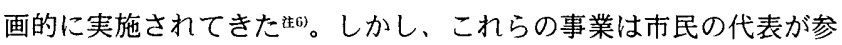
加する委員会等が設置されているものの、ほぼ行政の主導により進 められており、市民サイドの主体と連携する広がりを持つは至って いなかった。そのため、96年より都市M P の策定に取り組むことに なったことをきっかけにして、都市づくりのブロセスに協議の場を 設けて市民サイドの主体を巻き込む仕組みの構築が目指されること になった。具体的には、いくつかの課題について協議の場を設けて 市民サイドの主体を巻き込み、生まれてくる計画文書を都市 MP 中心に整理しながら、段階的に仕組みの構築に取り組んだ。以下で 考察の対象とするのは、96年以降の鶴岡のまちづくりの一連の取り 組みである。なお、対象とする全ての協議の場に対して筆者らがア ドバイザーとして関わっている。

\section{2 ) 鶴岡のまちづくりの位置づけ}

96 年 2 月より 01 年 6 月にかけて、協議の場では表 1 に示す課題が 議論された。これらの課題を、課題への行政サイドの熟度、および 市民サイドの主体の有無の 2 軸で類型化し（図 2 ） 主》、その位置づ けを述べておくと、行政サイドの熟度が低く、市民サイドの主体が 見あたらない課題（第而象限：ACDE）から協議が始められ、や がて行政サイドの熟度が高い課題（第IV象限：B F H）の協議が行 われた。市民サイドの主体がいないために、公募を行ったり、既存 の組織に声をかけるなどして協議の場への参加者が集められた。 


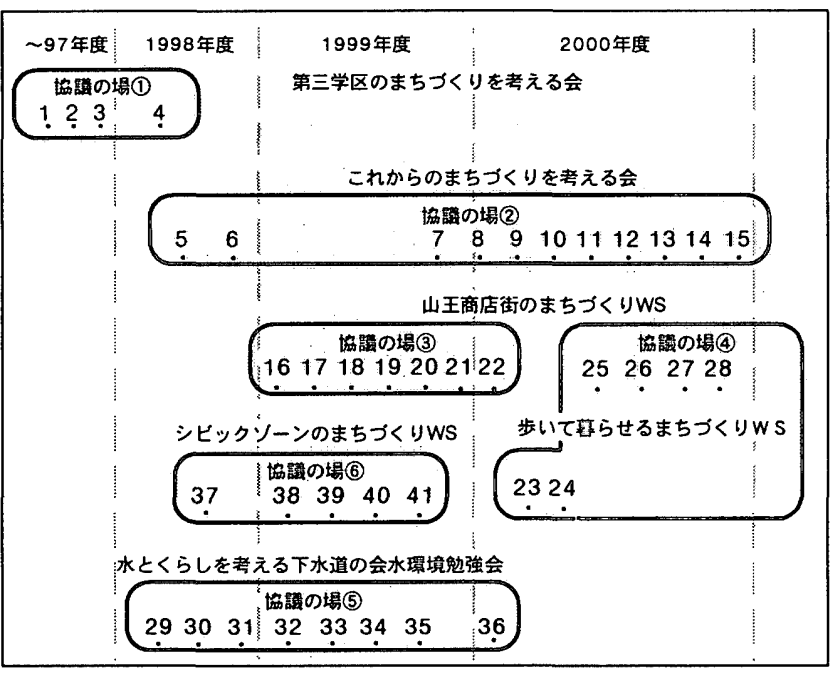

※注 困中の1〜41の数字は、各「協謡の場」を構成した個別の会合を示し、表 3 の困中のWS $\sim 41$ に对応している

※注 ワークショップはWSと略記している。

\section{図 3 協䛔の場の一覧}

都市によっては第 II 象限、第 I 象限の取り組みが中心となる場合 もあり、その場合協議の場の設定を、市民サイドの主体と共同で行 うことになる。鶴岡の取り組みは上記のような位置にある課題につ いて、行政サイドが主導して協議の場を設定した事例である。

\section{3）協議の場の概要}

協議の場は、図 3(1)〜6に示す通り開催された。これらは01年 6 月の段階でほぼ完結した計画文書がまとめられている協議の場せ8で ある。図 3 の通り $1 \sim 41$ の S によりそれらは構成され、それぞれ の協議プロセスの中で計画文書が発行された。

図 1 のモデルに沿って、協議のプロセスと発行された計画文書を 整理したところ（表 3 )、ア〜ヒの 27 種の計画文書が確認された。 以下 4）～6）に都市MPの策定を課題（A〜E）にした協議の場 (1)(2)、中心市街地の活性化を課題（F G）にした協議の場(3)(4)、個 別具体的な課題（EH）について協議をした協議の場(5)6の 3 つの 流れに分けて、協議の場の概要とそこで生み出された計画文書の決 定タイプ、プロセスタイプをまとめ、その詳細を図 4 にまとめる。 なお、本文中、および表 1～2、図 2 4 4 に示す英大文字 $(\mathrm{A} \sim \mathrm{H})$ は課題に、丸数字（1〜（6)）は協議の場に、カナ文字（ア〜ヒ）は 計画文書にそれぞれ対応している。

\section{4 ）都市計画マスタープラン策定を目指した協議の場}

協議の場(1)は、都市MPの策定にむけて、試行的に開催された。 行政が住民と議論をする中で、都市MP策定の方法を探るという目 的が持たされ、行政が課題 $\mathrm{ACDE}$ を提示し、参加者がそれについて 議論を行い、その結果を行政が「まちづくり瓦版」や「まちづくり 情報帳」にまとめるというプロセスがとられた。プロセス・決定夕 イプは図 4 に示す通りであるが、途中型の「白書」(文書ア〜ウ) が成果型の文書才とオー 2 に、途中型の「提案」（文書ア〜ウ、カ） が、成果型の文書エにまとめられた。

協議の場(2)は、協議の場(1)での試行を全市的に広げ、都市MPの 表3＼cjkstart協閵のプロセスと計画文置の関係

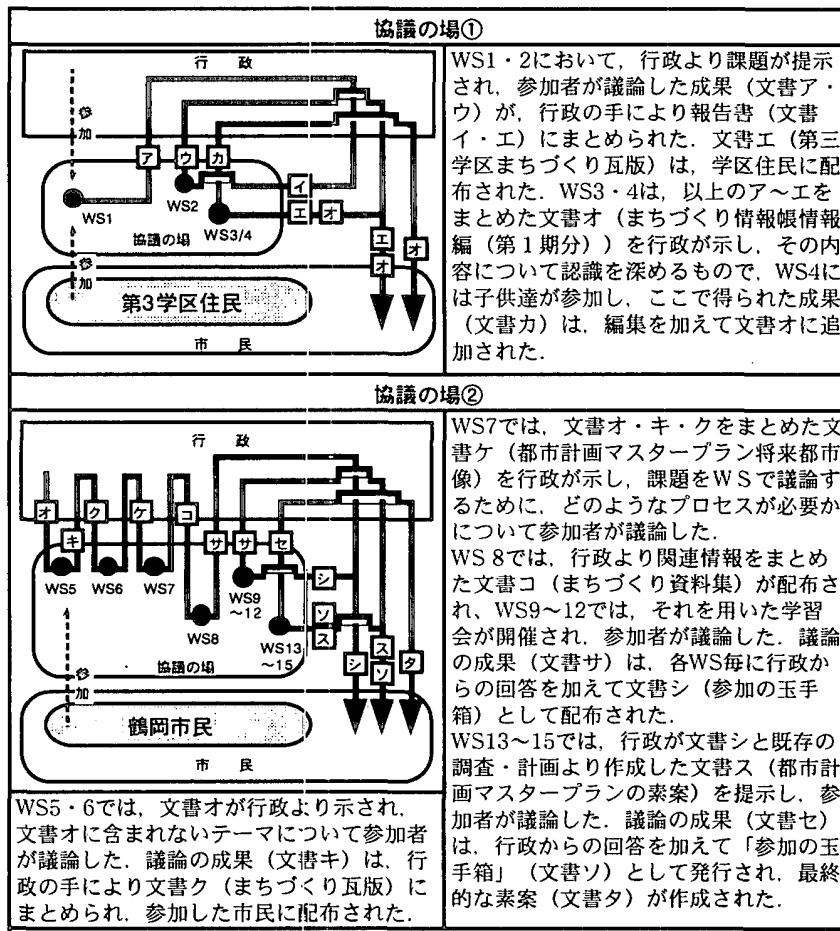

まとめられ、参加した市民に限布された。

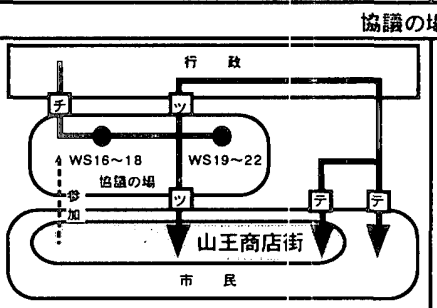

WS16〜18では，行政より文書于が提示 され，参加者が議詇し，提案集 (文書 ツ) をまとめた. WS19〜22では, 文書 ツの提案について，勉強会を量ねながら 商店街の組織内部で事業化を検时する

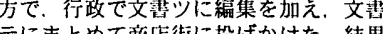
テにまとめて陌店街に投げかけた。結果 として附店街による或業化が決まらない まま、協議の場は終了した。

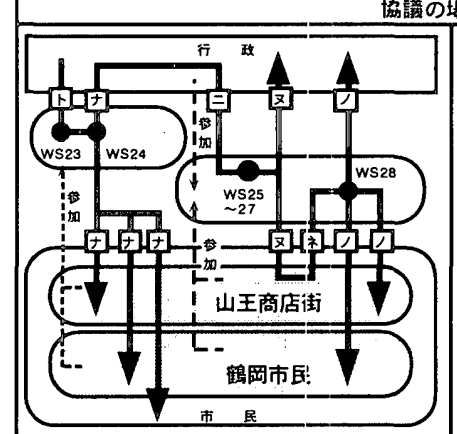

WS23〜24では，行政より関連情報をま とめた文徣卜（中心市街地事菜集）が提 示され、それをたたき台にして参加者が 誘論し，それらを絞り込んで文悲ナ（39 の提案集) を作成した.WS25〜28で は、まず行政とコンサルタントが文書ナ で挙げられた提案の假先順位. 取り組む

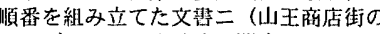
まちづくりのシナリオに関するメモ）を 提案した.WSの場で議論されると共

に、商店街組織の内部で文書邓が検討さ 机、文悲ネ（山王商店街からのまちづく り提案) がWSに提出された. 文書ネを たたき台にして行政。市民が対応を議論

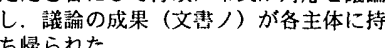
坮覆の埸(5)

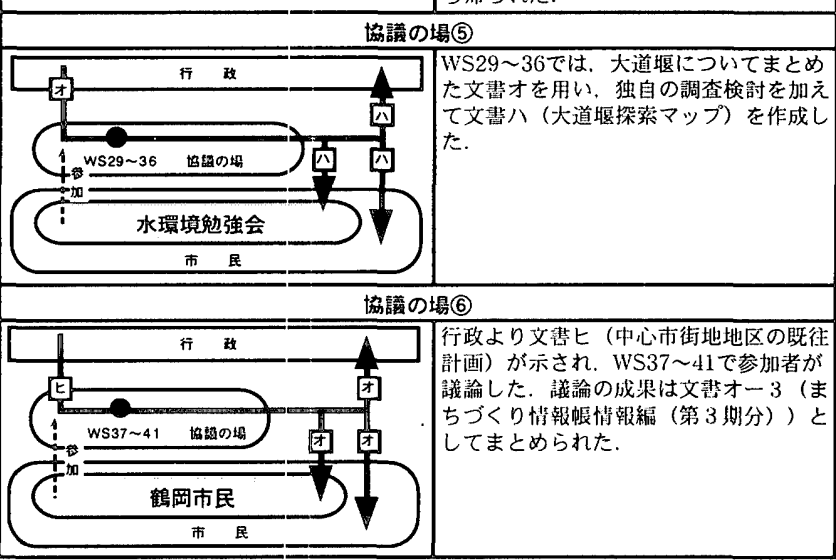

[凡例］○協議の場における個别の会合 (WS) を示す

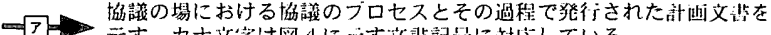
示す。力ナ文字は図 4 に六す文悲記桨に対忍している 肪尼㑬の主体を示す 
全体構想を策定することを意図していた。WS5・6では、事前型の 文書として文書オが示されて議論が行われ、成果型の文書クがまと められた。WS7〜15は、それまで議論された課題のうち、課題B1 〜B5.について行政が都市MPの分野別構想の素案（文書ス・夕）を 作成するために開催された。市民に文書才、それまで蓄積された 「提案」（文書エ・カ・ク）をまとめた文書ケ、分野別構想に関連す る既往計画や行政の内部で議論した案をまとめた文書コを示して意 見や提案を聴取し、それらを「方針」である文書ス・夕に反映させ る、というプロセスがとられた。協議の場で得られた途中型の文書 は文書シ・ソにまとめられて外部に発信された。

\section{5 ）中心市街地活性化の事業づくりを目指した協議の場}

協議の場(3は、課題Gについて中心市街地の商店街の一つである 山王商店街を対象に開催された。行政は既に公共事業を中心とした 中心市街地活性化基本計画（文書チ）をまとめており、文書チを事 前型の「提案」として商店街組織に示して議論し、新たに商店街組 織が展開する事業を見いだすことを意図していた。WSで「提案」 （文書ツ）が議論されたが、商店街組織で事業化の意志決定がされ ず、文書ツをまとめた成果型の文書テが作成された。

協議の場(4)、課題FGについて、商店街組織のみではなく、市 民も広く参加可能な協議の場を開催し、市民と商店組織街が協力し ながら実施する「方針」（文書ノ）の作成を行った。事前型の文書 トが示され、文書ノ以外の成果型としてWSで市民が議論した「提 案」（文書ナ）がまとめられ、それを商店街組織が絞り込んだ途中 型の「提案」(文書ネ) がまとめられている。

\section{6 ）個別の課題に対する協議の場}

協議の場(5)は、課題Dについて協議する場である。行政の方針が 中途で変化し、課題の解決を急がなくなったため「白書」「提案」 （文書八）が成果型としてまとめられた。

協議の場(6)、課題Hについて、市民が提案作成を通じて問題意 識を形成することを意図した場であり、「白書」「提案」（文書オー 3）が成果型としてまとめられた。

\section{5 計画文書の体系化の方法}

\section{1 ) 鶴岡の都市M Pの構成}

鶴岡では、以上 5 年間の取り組みで発行された、27種の計画文書 がまとめられ、都市M P に位置づけられて発行されている。全ての 計画文書が同時に発行されないため、完結した書籍の形ではなく、 加除が可能なバインダー形式でまとめられている。

現在示されている計画文書の体系は図 5 泣りの通りであるが、01年 6月の段階で発行されているのは、「全体構想」と「まちづくり情報 帳」の一部であり、「地域別構想」についてはまだ発行されていな い。以下に図 5 に沿って、どのような方法で計画文書の体系化を行 っているか報告し、かつ今後の課題を整理する。

2 ) 全体搆想、地域別構想

\begin{tabular}{|c|c|c|c|c|c|}
\hline \multirow{2}{*}{$\begin{array}{l}\text { 增議 } \\
\sigma \\
\text { 場 }\end{array}$} & \multirow{2}{*}{$\begin{array}{l}\text { 文書 } \\
\text { 記号 }\end{array}$} & \multirow[b]{2}{*}{ 計画文書の名称 } & \multicolumn{3}{|c|}{ 決定タイプ・ブロセスタイプ } \\
\hline & & & 事前型 & 8. & 成果型 \\
\hline \multirow{7}{*}{ (1) } & $\mathcal{P}$ & 議事録 & & & \\
\hline & 1 & $\begin{array}{l}\text { 第三学区まちづくりを考 } \\
\text { える会報告書 }\end{array}$ & & & \\
\hline & ウ & 議事録 & & & \\
\hline & $I$ & 第三学区まちづくり瓦版 & & & \\
\hline & オ & $\begin{array}{l}\text { まちづくり情報帳情報編 } \\
\text { (第1期分) }\end{array}$ & & & \\
\hline & 力 & 議事録 & & () & \\
\hline & オ -2 & $\begin{array}{l}\text { まちづくり情報帳情報編 } \\
\text { (第2 } 2 \text { 期分) }\end{array}$ & & & \\
\hline \multirow{12}{*}{ (2) } & オ & $\begin{array}{l}\text { まちづくり情報帳情報編 } \\
\text { (第2 } 2 \text { 期分を加えた) } \\
\end{array}$ & & & - لـ \\
\hline & キ & 議事録 & & & \\
\hline & ク & まちづくり瓦版 & & & (1) \\
\hline & ケ & $\begin{array}{l}\text { 都市計画マスタープラン } \\
\text { 将来都市像 }\end{array}$ & & & \\
\hline & ב & まちづくり資料集 & (a) (a) & & \\
\hline & サ & 議事録 & & (c) & \\
\hline & シ & 参加の玉手箱no.0 no. 5 & & & \\
\hline & サ-2 & 議事録 & 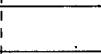 & (c) & \\
\hline & ス & 素案 & 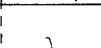 & & $一$ \\
\hline & セ & 議事録 & & 2,1 & \\
\hline & ソ & 参加の玉手箱no.6～no.8 & & & \\
\hline & 夕 & $\begin{array}{l}\text { 都市計画マスタープラン } \\
\text { (全体構想の一部) }\end{array}$ & I & & \\
\hline \multirow{3}{*}{3} & 于 & 中心市街地活性化基本計画 & (a)- & & \\
\hline & ツ & 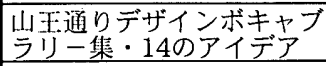 & & & \\
\hline & テ & $\begin{array}{l}\text { 住み続けられるまち研究 } \\
\text { 事業報告畫 }\end{array}$ & i & & (1) @ \\
\hline & ト & 中心行街地事紧集 & $\sqrt{6}$ & & 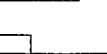 \\
\hline & ナ & 39の提案集 & 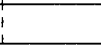 & (1) (d) & (e) \\
\hline & 二 & $\begin{array}{l}\text { 山王謪店街のまちづくりの } \\
\text { シナリオに関するメモ }\end{array}$ & & (s) & \\
\hline & 又 & 議事録 & & (c) (1) & \\
\hline & ネ & $\begin{array}{l}\text { 山王商店街からのまちづ } \\
\text { くり提案 }\end{array}$ & & & \\
\hline & 人 & 素案 & -7 & & 00 \\
\hline \multirow[b]{2}{*}{ (5) } & t & まちづくり情報帳情報編 & (a) & ․ & \\
\hline & 八 & 大道殹探索マッブ & & & (이) (1) \\
\hline \multirow[b]{2}{*}{ (6) } & 匕 & 中心市街地地区の既往計画 & (a) & 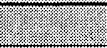 & \\
\hline & t -3 & 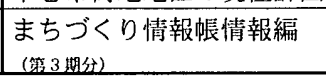 & & & (2) \\
\hline
\end{tabular}

図中の ○は決定夕イプの「白書」に，团は「提案」に，は「方釗」に対 応している. また, アルファベットは, ブロセスタイブ（aｏ）に対応して いる. 一一㥀接的に編集された関係を, - - は は同じ計画文韭であること を示す

图4 計画文書の決定タイプ及びプロセスタイプ

全体構想は「鶴岡市全体の都市計画の方向性をまとめたもの（図 5 )」、地域別構想は「小学校区毎に住民の皆さんの指針となる詳細 な計画をまとめたもの（図 5 )」であり、協議の場を経て生み出さ れた「方針」がおさめられる。

全体構想は、協議の場(2)(3)において、行政が白書や提案を編集し て示しながら情報を集めて素案を作成し、文書夕に成果型としてま とめられた。協議のブロセスで得られた途中型の情報（文書セ）は、 
ニュース（文書ソ）と文書夕甘10にまとめられている。

地域別構想は、図 5 に示すとおり「行政の計画」「協働の計画」 「コミュニティプラン」「まちづくり単位別構想」の 4 つに分けた体 系化が考えられている。「行政の計画」「協働の計画」「コミュニテ イプラン」は、小学校区毎にコミュニティ協議会を介して協議の場 を設けてまとめることを、「まちづくり単位別構想」は、一つの課 題に対してまとまりのある範囲（例えば、商店街の範囲や地区計画 の範囲、河川の流域の範囲など) で住民組織と協議の場を設けてま とめることを想定している。

「行政の計画」「協衝の計画」「コミュニティプラン」は地域別構 想策定がそれぞれ図 2 のどの象限に位置するかに対応しており、地 域に行政から見て課題があり、かつ住民側の熟度が低く行政がイ二 シアティブを取る場合（第IV象限）は「行政の計画小、逆に住民か ら見て課題があり、行政側の熟度が低く住民がイニシアティブを取 る場合（第 II 象限）は「コミュニティプラン」、双方の熟度が高く 協働で行う計画を立案する場合（第 I 象限）は「協働計画」という 3 パタンを想定している。既述の通り、鶴岡で行政側から見た課題 が比較的顕在化しているのは第 3 学区に多くが含まれる中心市街地 せ11であり、第 3 学区については、協議の場(1)をはじめとする行政 からの投げかけがある。しかし現段階でコミュニティ協議会には自 らを実行主体にした計画を立案する意志は無く、「提案」と「白書」 だけが得られている。もちろん今後の協議に拠るが、第 3 学区につ いては、文書チ・トをたたき台にした「行政計画」が協議の場にお ける住民との議論を経て作成され、その過程で得られた「白書」や 「提案」が「まちづくり情報帳」にまとめられることになる゙涉22。

「まちづくり単位別構想」は、特定課題に取り組む住民組織の存 在がその策定の前提にあり、現在は山王商店街において取り組みが 進められている。協議の場(5において「提案」を絞り込み、「方針」 がまとまりつつあり、今後都市M P に位置づけられていく。

\section{3）まちづくり情報帳}

まちづくり情報帳（以下情報帳）は、「これまでの市民参加のま ちづくり活動で蓄積した課題やアイデア、調査研究の結果などをま とめたもの（図 5)」であり、協議の場を経て生み出された「白書」 と「提案」がおさめられる。図6に示すとおり、その内部はさらに 「まちづくり情報編」「まちづくり知恵袋編」「まちづくり実践編」 「まちづくりニュース編」に分かれている。情報編は文書才、ニュ 一ス編は文書エ・ク・シ・ソ、実践編は文書八がそのままおさめら れている。知恵袋編はワークショップの技法をまとめたものであり、 本稿の考察の対象ではない。

情報帳に納められている「白書」について述べると、協議の場(1) で途中経過的に蓄積された文書ア・イ・ウ・カが「まちづくり情報 帳情報編」（文書オ）と「ニュース」（文書エ）として成果型にまと められ、これらが以後の協議の場(2)、(3)、(6)、(7)において事前型の 情報（a）として行政から提示され、そこで加えられた情報が二ュ

\begin{tabular}{|c|c|c|}
\hline 全体搆想 & 地域別構想 & まちづくり情報帳 \\
\hline 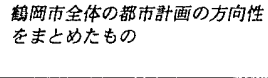 & 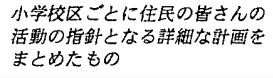 & \multirow{4}{*}{ 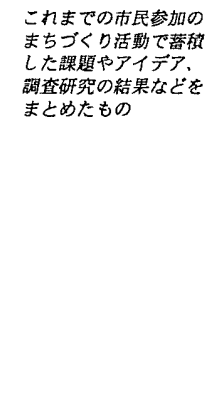 } \\
\hline $\begin{array}{l}\text { 基本構想 } \\
\text { 将来都市像/ブランの構成／ } \\
\text { 役割/区域の設定／運嘗／市 } \\
\text { と市民の役割 } \\
\end{array}$ & \multirow{2}{*}{ 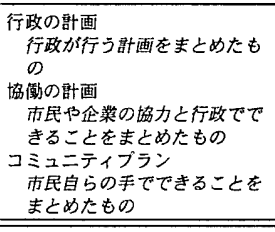 } & \\
\hline 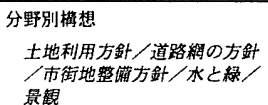 & & \\
\hline 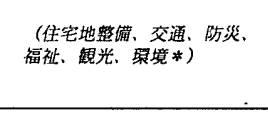 & 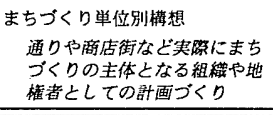 & \\
\hline
\end{tabular}

※分野别骤想のテーマについては，すべてのデーマについてブランをつくろのてはなく、必要な部分か ら話し合いを秙け、出来上がったと:ころからブランに盛り込んでい。）に示すのは今後考えられる 参考テーマでる.

図 5 鹪岡における計画文書の体系

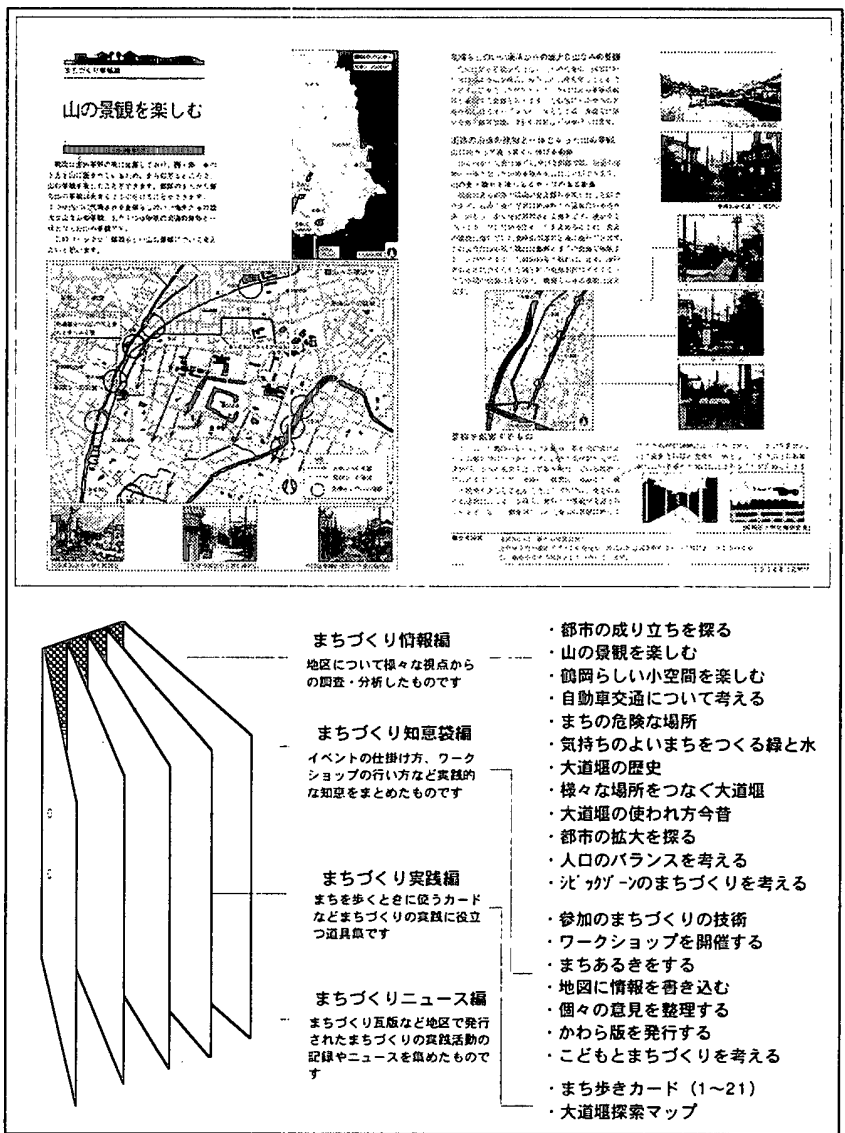

园 6 まちつくくり情報帳のページ構成（上）と目次（下）

一ス（文書ク・シ・ソ，マップ（文書八）、情報編（文書オー3） として成果型にまとめられた。このように、まとめられた情報帳は、 今後新たな協議の場が設けられたときに事前型の計画文書（a）と して協議の場に提出さ礼ることが想定されている。ニュース、マッ プ、情報編とまとめ方が異なるが、すでに当該課題について情報編 があり、協議の場において新しい情報が得られなかった場合は二ュ 一スやマップにまとめられている。

情報帳におさめられている提案について述べると、事前型の計画 文書としては、課題に関連する行政内部の計画（情報コ・チ・ト・ ヒ）と協議の場で蓄積された提案をまとめた情報（文書ケ）がある。 
そして、これらに対する「提案」が出され（文書ア〜ウ・カ・キ・ サ・シ・セ・ッ・ナ〜ネ)、「方針」へと練り上げられたものを除い て、これらが「提案」（文書シ・ソ・テ・ハ・オー4）として成果 型にまとめられた。成果型は、ニュースとして発行されている場合 は、情報帳のニュース編におさめられている。ニュースとして発行 されていない場合（情報テ・ハ）は、現段階で計画文書の体系に位 置づけられておらず、後述する地域別構想の策定と併せて「まちづ くり情報帳提案編」等にまとめる必要がある。「提案」は、課題が 顥在化し、行政や市民サイドのまちづくりの主体がその「提案」を 採用すれば、「方針」へと格上げされるものである。そのため、協 議の場に直接参加しなかった市民に内容が明確に伝わることが必要 である。

\section{4) 都市MPの運用}

鶴岡は行政サイドから見ると、全体としてあまり課題を抱えてい ない。そのため今後は、地域別構想や全体構想は主に市民の気運が 熟したところから協議の場を経て作成され、その過程で生み出され た「白書」や「提案」が情報帳に追加されていく。

これまでは市民サイドの主体がいない課題（図 2 の第III・第IV象 限）の協議が行われたため、行政が情報を十分に伝えながらの取り 組みが行われた。そのため、計画文書のプロセスタイプは行政から 直接発せられる $\cdot \mathrm{g} \cdot \mathrm{j} \cdot \mathrm{k}$ (表 1 参照)、あるいは行政が設けた協 議の場から発せられるc〜e（表 1 参照）が多い。一方で、課題 $G$ （図 2 の第 I 象限）については、上記のものに加えて、市民サイド の主体からプロセスタイプhの計画文書が発せられた。今後顕在化 する新たな課題に対し、市民サイドの主体が積極的な活動を展開す る場合（図 2 の第 I ・II 象限）には、タイプhに加え、市民サイド の主体から発せられるタイプ $\mathrm{b} \cdot \mathrm{m} \cdot \mathrm{n} ・$ 。（表 1 参照）の計画文書 は増えていくは8。

これらを計画文書体系へのおさめる際の課題について考察をして おくと、例えば、苦情や陳情を無批判に束ねたようなものが市民サ イドの主体から $\mathrm{b} \cdot \mathrm{h} \cdot \mathrm{m} \cdot \mathrm{n} \cdot \mathrm{O}$ とし提出された場合にどう位置 づけるか、という課題が想定される。これについては、情報を計画 文書体系に位置づけする「協議の場」の「手続き」を明確化してお く必要がある。協議を経て不要な情報が絞り込まれ、課題とそれに 対する市民と行政の決定の度合いが明確になることが協議の場の機 能であり、この機能を担保するために協議の場のルールを明確化す る必要がある。協議の場が開かれていること、透明性の高い場であ ることは当然であろう。

\section{5 ) 都市M Pの果たす役割}

最後に、以上のように都市 MPを中心に構築されている情報基盤 が、鶴岡のまちづくりにおいてどのような役割を果たしつつあるの か、考察しておく。

本研究では、図 3 に示す 2000 年度中に完結した計画情報がまと められた協議の場を対象としているが、これら以外に複数の協議の
場が進行中である諳8詳細については記述しないが、それまでの協 議の場がきっかけとなり、市民が主導して始められた取り組みであ る。また、行政サイドでは以上の取り組みを支援すると共に、協議 の場(3)を通じて作成した都市MPの全体構想「市街化の方針」に沿 って、線引きの導入の検討、地元説明会を行っている。

以上の展開を踏まえ、そこに都市 M P の果たしている役割につい て考察しておく。

(1)計画情報の共有 : 協議の場に直接関わった主体はもちろんである が、そこに関わっていない主体が、後日に詳細な情報を共有出来る 情報基盤となっている。既述の通り、まちづくりは多主体により運 営され、その主体は常に変化する。実際に鶴岡においても、新たな 協議の場が開かれ、そこに新しい主体が参加し、新たなまちづくり の担い手となるケースが見られる。新たな主体が参画する際に障壁 の一つとなるのが、それまでの主体との間にある情報量の格差であ ると考えられるが、その格差を少なくし、新たな主体がまちづくり に参画しやすい状況を作り出している世13)。

(2)計画情報の理解とビジョンの共有：「白書」「提案」「方針」にそ って、計画情報を体系立てて理解することができ、そのことが結果 として都市づくりのビジョンの共有化につながっている。例えば情 報帳では数頁にわたって中心市街地に残る城下町時代の街路の魅力 や可能性がまとめられているが、情報帳は市民の中で人気が高く、 実際に自主的な学習会等でもテキストとして用いられている。かつ ては言及されることの少なかった街路空間の魅力を広くアピールす ることにつながっており、このことが、結果として「歷史的基盤の 残る中心市街地を重視する」という鶴岡のまちづくりのビジョン、 あるいは全体構想で「方針」として位置づけられている線引きの実 施などの諸施策が共有化されることにつながっている。

(3)まちづくり施策の一貫性 : 都市M P を固定的なものにせず、まち づくりの取り組みの進捗にあわせて蓄積されていくものとしたた め、個別の施策の実施時や協議の場での議論において、常に都市 $\mathrm{M}$ $\mathrm{P}$ との関係を参照することになり、結果として施策に一貫性が生ま れている。

\section{6 結語}

本研究は、都市計画の「課題と主体の多様化」を背景に、中長期 的に多主体で個別的に展開されるまちづくりの中で発行される各種 の計画文書を集積する情報基盤としての都市M P の作成の方法を示 した。具体的には、個別のまちづくりや都市M P 策定における協議 のプロセスで発行さ扎た計画文書を、「決定タイブ」と「プロセス タイプ」から区別し、区別に基づいた計画文書の体系化の方法を示 した。

従来の都市計画における「マスタープラン」は、都市の課題に対 する現状認識、行政が実行する規制誘導や公共事業の方針と、市民 や事業者に対する提案で構成されている。これらの計画文書を本研 
究で定義した「決定タイプ」と「プロセスタイプ」で区別すると、 協議を経ていない「白書」「提案」「方針」は、全て事前型の計画文 書であり、本研究で示した方法はこのような計画文書を、協議の場 を通じて市民と議論し、少しづつ市民サイドの主体と共有のマスタ 一プランに置き換えていく方法であるとも言える。多くの都市にお いて、市民と行政が協働しながらまちづくりに取り組む体制への転 換が図られている。その体制を支える情報基盤として、本研究で示 したような方法を持って都市MPの策定に取り組むべきであろう。

\section{謝辞}

本研究は、筆者が所属する早稲田大学理工学総合研究センター、 早稲田大学都市地域研究所が山形県鶴岡市、鶴岡市 $\mathrm{T} M O$ 、建設省 東北地方建設局秋田営絲工事事務所、都市づくりパブリックデザイ ンセンターより委託を受けて行った調査をもとにしています。関係 各位および調査にご協力いただいた鶴岡市民の皆様に記して感謝の 意を表します。

注

注1）都市計画に関連するマスタープラン策定への市民参加の取り組みは、 地方自治法による基本構想の策定が取り組まれ始めた 69 年以降より見 られるが、特に 92 年の都市計画法の改正により都市 M P が創設され、 そこに市民参加のブロセスが位置づけられたことがきっかけとなり、 多くの自治体で取り組みが行われ、さらには個別具体の課題について も市民参加型のまちづくりが取り組まれ始めたという状沇がある。

注2）都市M P が創設されたのは92年であるが、従来より独自のマスターブ ランを持って都市計画に取り組んでいた先進自治体を除き、策定には3 年程度を要する。そのため、都市 M P を策定し、さらに個別の参加型 まちづくりに取り組んで実績や望題が明らかになっている市区町村の 事例は少数であると考えられる。

注3）この定義について、完全に市民間で行われる行為についてどう考える かが論点となる。例えば多くの市民版マスターブランは、最終的に行 政に対して提言的にマスターブランをまとめるまで、有志の市民によ つて作成されている。筆者は市民間で行われる行為の中で、一定の要 件を满たしたもの、例えば「市民間で設けられた協議の場に誰でも参 加することが出来、結果的に行政の参加が見られなかった場合」など については「まちづくり」と見なすべきだと考えているが、本論で 「一定の要件」について考察する紙幅がないこと、本論後半で扱う鶴岡 市の事例が行政サイドの主導で行われたことから、このような限定的 な定義とした。

注4）町田の取り組みは総合計画づくりへの参加ではなく、個別具体的な課 題における実質的な市民参加を重視した。個別の課題每に市民参加で 協議と実践を重ね、一連の取り組みが「考えながら歩くまちづくり」 と題したレボート（文献6）にまとめられ、そのレボートが市の基本構 想に相当するとされている。

注5）コミュニティ協議会は鶴岡市において小学校区每に設けられている組 織であり、学区毎に設置されたコミュニティセンターの管理楎営を行 うほか、自主的な事業を行っている。

注6）景観形成基本計画は、中心市街地とその周辺エリアおよび刘外の区画 整理地区の景钼整備方針を定めたものである。リーディングブロジェ クトとして河川や橋の改修方針が位置づけられ、このフログラムに沿 って、中心市街地における公共空問の整備が進められている。また中 心街地区整備基本計画をはじめとして、中心市街地には大規模な施設 等の整備ブログラムがあり、シビックコア地区整備計四、荘内病院の 移転新築、東北公益文科大学大学院建設などの事業が進行している。

注7）広原は文献8において、「(住民の) 主体性䫓在地区（と非顕在地区）」 と「問題地区（と非問題地区）」の 2 軸で「大都市におけるまちづくり 一般モテル」を提示している。インナーシティを抱える大都师睡成市 街地を前提とし、地区を類型して、そこでのまちづくりのモデルを提 示したものである。図2 は、このモデルを地方都市の少望ではない市
街地の整備を念頭に改めたものである。具体的には，広原は神戸市に おける「地区まちごくり」を念頭に、様々な課題を包摄する「地区」 を整備の単位としで捉えているが、本研究で対象とするまちづくりは 「課題」毎に展開されることも念頭に置いている。したがって、「地区」 を「課題」にあらだめた。また、広原は数値などで客観的に評価しう る客観的問題状況を:重視し「問題地区」の軸に据え、行政が公共投資 をすべき領域を類型している。しかし、地方都市の場合、明らかに劣 悪な問題がある場合を除き、協議の場などにおいて多くの主体が相互 主観的に評価を形成するしかない課題が多く、客観的な問題地区の特 定は難しく、そのまま公共投資をすべき領域かどうかの判定は難しい。 したがって、「問題地区」の軸を、「行政がその課題に対して取り組む 熟度が高まっているかどうか」に改めた。

注8）本研究で取り上げだ事例以外に、複数の協議の場が進行中である。「つ るおか街かど文学館」は、市民が中心となって実行委員会を結成し、 空き店舗などを活用した実験的な「街かど文学館」の開設といった害 践と協議を重ねて、常設的な「街かど文学館」の設立可能性を検討し たものである。協諓の場(出がきっかけとなり、2001年度中にわたって 協議の場が設けられた。また、「五学区のまちづくりを考える会」は、 鶴岡市第 5 学区に拧いて、2001年2月にコミュニティ協議会が主導し て設立した協議の場であり、都市M P 地域別構想策定に向けた活動を 行っている。このように、市民主導の協議の場が増加しつつある。

注9）鶴岡市都市計画マンタープランに示されている「都市計画マスターブ ランの役割・構成よ内容」を転記したものである。図示されていると おり，「全体構想」「地域別構想」に加えて「まちづくり情報帳」が, 都市計画マスターブランの計画文書の体系の中に位题づけられている。

注10）都市MPの全体莩想には、「よくある質問・提言集」という一節が設け てあり、文書セ等において多く出されている計画に対する意見につい て、個別にその回答が記されている。

注11）小学校区の多くは倠岡市の中心から郊外に向けて区域が設定されてお り、行政で設定している中心市街地には第 $1 \sim 6$ 学区が含まれている。 第 3 学区はその多くを占めている。

注12）第 3 学区では、地惐別構想をまとめるべく2001年10月以降数回のWS を開催しており、䍐在も継続中である。

注13）例えば「街かど文学館」の中心的なメンバーであるN氏は、2001年4 月以降よりまちづくりに携わる人物であるが、「これまでの議論の経 觡がまとめてあることによって状況を理解することが容易であり、新 たにまちづくりに参画することが容易であった」という旨の発言を、 都市計画課の主催するシンボジウム（2001年度開催）で行っている。

\section{参考文献}

1）渡辺俊一：「参加はそこまで」を越えてーマスターブランへの市民参加 をいかに貫徽するかー,アーバンアドバンス,第21号,pp.11〜17,2001.3

2）渡辺俊一,太田守莘他：市民版まちづくりブラン実践ガイド, 学芸出版 社, 2001.9

3）大和田清隆,小泉秀樹,大方潤一郎：都市計画マスターブラン策定過程へ の参加を契機とした市民活動の展開に関する研究,都市計画別冊平成 12 年度都市計画諭文集,第35号,pp.217 222,2000.11

4）内田晃,他 5 名: 地方都市の都市計画マスタープランにおける策定ブロセ スと住民参加に関する研究一九州地域74自治体におけるケーススタディ による㭘証-,都市計画別冊平成 10 年度都市計画論文集,第33号,pp.457 $\sim 462,1998.11$

5）浅野聡 : 市民ワークショッブによる成長するプランブくり,市民参加のま ちづくり,学芸出版社.,1999.2

6）町田市長期計画策定特別委員会：考えながら歩くまちづくりへの 提, 1973.8

7）田村憲二：足立区地区環境整備計画と都市計画マスターフララン,月刊自治 研,第37巻435号,pp.134 72,自治研中央推進委員会, 1995.12

8）広原盛明：神戸市まちづくり政策の転換と多様化,霞災・神严都市計画の 検証, pp.85 90,自治体研究社, 1996.1

(2002年 1 月 9 日原稿受理， 2002 年 8 月 22 日採用決定) 